\title{
KARABEMYCIN, A NEW ANTIMETABOLITE OF GLUTAMINE PRODUCED BY A STRAIN OF STREPTOMYCETE
}

\author{
Satoshi Ōmura, Akira Nakagawa, Hiroshi Aoyama \\ and Yuzuru IwaI \\ Kitasato University and The Kitasato Institute, \\ Minato-ku, Tokyo 108, Japan \\ Masao Kuwahara and Takashi Furusato \\ Nissan Chemical Industries Ltd., \\ 1470 Shiraoka, \\ Minamisaitama-gun, Saitama, Japan \\ (Received for publication June 1, 1983)
}

\begin{abstract}
Karabemycin, a new peptide antibiotic, was isolated from the culture filtrate of Streptomyces sp. AM-6424, a soil isolate. The molecular formula of the antibiotic was determined as $\mathrm{C}_{15} \mathrm{H}_{24} \mathrm{~N}_{4} \mathrm{O}_{6}$ on the basis of elemental analysis, FD-mass spectrum and ${ }^{1} \mathrm{H}$ and ${ }^{13} \mathrm{C}$ NMR. Acid hydrolysate of karabemycin contains one mol each of valine, alanine and an unknown amino acid.

The antibiotic is active against Gram-positive and -negative bacteria on a synthetic medium. The inhibitory activity is reversed by L-glutamine and L-glutamic acid.
\end{abstract}

In the course of screening for new antibiotics of actinomycetes origin, we found that strain AM6424 isolated from a soil sample collected at Karabe, Narita City, Chiba Prefecture, Japan, produces a new peptide antibiotic which has been designated karabemycin. The antibiotic is active against some bacteria such as Bacillus subtilis PCI 219

Plate 1. Scanning electron micrograph of aerial mycelia of Streptomyces sp. AM-6424. Bar represents $1 \mu \mathrm{m}$.

and Escherichia coli IFO 12734 on a synthetic medium, and its activity is reversed by both Lglutamine and L-glutamic acid.

The present paper deals with the taxonomy of strain AM-6424 and the production, isolation, and biological and physicochemical properties of karabemycin.

Taxonomy of the Producing Organism

Morphology

The vegetative mycelium grows abundantly on both synthetic and complex agar media, and does not have septa. Velvety and powdery aerial mycelia were well produced on various agar media. Plate 1 shows scanning electron micrograph of aerial mycelium grown on inorganic salts - starch agar. The sporophores are of the

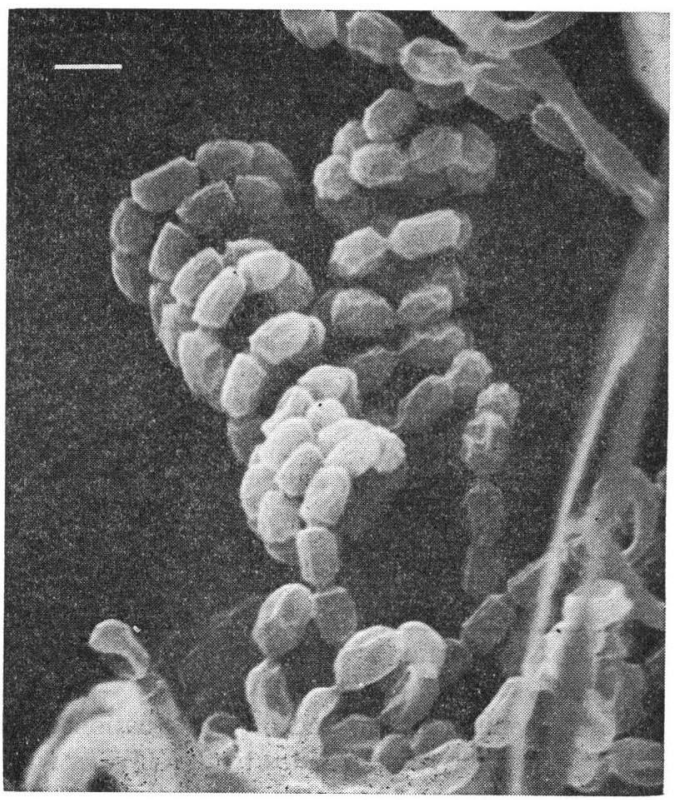


Table 1. Cultural characteristics of strain AM-6424.

\begin{tabular}{|c|c|}
\hline Medium & Cultural characteristics \\
\hline \multirow[t]{4}{*}{ Yeast extract - malt extract agar* } & G: Good, amber (3pc) \\
\hline & $\mathrm{R}:$ Orange rust (4pe) \\
\hline & AM: Moderate, light ivory (2ca) \\
\hline & SP: Bright yellow (3na) \\
\hline \multirow[t]{4}{*}{ Oatmeal agar* } & G: Good, mustard gold (2pe) \\
\hline & $\mathrm{R}: \quad$ Amber $(3 \mathrm{pc})$ \\
\hline & AM: Abundant, cottony, covert tan (2ge) \\
\hline & SP: Gold (21c) \\
\hline \multirow[t]{4}{*}{ Inorganic salts - starch agar* } & G: Good, mustard gold (2ne) \\
\hline & R: Gold (21c) and amber (3pe) \\
\hline & AM: Abundant, velvety, white (a) \\
\hline & SP: $\quad$ Light gold $\left(1 \frac{1}{2} \mathrm{~kb}\right)$ \\
\hline \multirow[t]{4}{*}{ Glycerol - asparagine agar* } & G: Good, squash yellow (2ie) \\
\hline & R: Golden yellow (2ob) \\
\hline & AM: Abundant, velvety, light ivory (2ca) \\
\hline & SP: Golden yellow $(2 \mathrm{~kb})$ \\
\hline \multirow[t]{4}{*}{ Glucose - asparagine agar } & G: Good, gold (2lc) \\
\hline & $\mathrm{R}: \quad$ Amber (3pc) \\
\hline & AM: Abundant, velvety, white (a) \\
\hline & 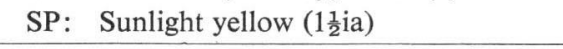 \\
\hline \multirow{4}{*}{ Peptone - yeast extract - iron agar* } & G: Good, beige brown (3ig) \\
\hline & $\mathrm{R}: \quad$ Mustard tan (2lg) \\
\hline & AM: None \\
\hline & SP: Poor, light mustard tan (2ie) \\
\hline \multirow[t]{4}{*}{ Tyrosine agar* } & G: Good, golden brown (3pg) \\
\hline & R: Golden brown (3pg) \\
\hline & AM: Abundant, velvety, pale yellow (1ca) \\
\hline & SP: Squash yellow (2ia) \\
\hline \multirow[t]{4}{*}{ Sucrose - nitrate agar** } & G: Moderate, ivory (2db) \\
\hline & R: Ivory (2db) \\
\hline & AM: Poor, light ivory (2ca) \\
\hline & SP: None \\
\hline \multirow[t]{4}{*}{ Glucose - nitrate agar** } & G: Good, light amber (3ic) \\
\hline & $\mathrm{R}: \quad$ Amber $(3 \mathrm{nc})$ \\
\hline & AM: Abundant, velvety, ivory (2db) \\
\hline & SP: Bright yellow \\
\hline \multirow[t]{4}{*}{ Glycerol - calcium malate agar** } & G: Good, gold $\left(1 \frac{1}{2} n c\right)$ \\
\hline & R: Mustard gold (2nc) \\
\hline & AM: Poor, parchment $\left(1 \frac{1}{2} \mathrm{db}\right)$ \\
\hline & SP: Light olive gray ( $1 \frac{1}{2}$ ge $)$ \\
\hline \multirow[t]{4}{*}{ Glucose - peptone agar** } & G: Good, dark luggage tan (4pg) \\
\hline & $\mathrm{R}: \quad$ Orange rust $(4 \mathrm{pe})$ \\
\hline & AM: Abundant, velvety, white (a) \\
\hline & SP: Oak brown (4pi) \\
\hline \multirow[t]{4}{*}{ Nutrient agar** } & G: Moderate, light mustard tan (2ie) \\
\hline & R: Mustard brown (2pi) \\
\hline & AM: Poor, white (a) \\
\hline & SP: Bamboo (2gc) \\
\hline
\end{tabular}
A

* Medium recommended by International Streptomyces Project.

** Medium recommended by $\mathrm{S}$. A. WAKSMAN. 
Table 2. Physiological properties of strain AM-6424.

\begin{tabular}{|c|c|}
\hline & Response* \\
\hline Melanin formation & $+* *$ \\
\hline Tyrosinase reaction & - \\
\hline Nitrate reduction & - \\
\hline Hydrolysis of starch & + \\
\hline Liquefaction of gelatin & $-\left(22^{\circ} \mathrm{C}\right)$ \\
\hline Peptonization of milk & $+\left(37^{\circ} \mathrm{C}\right)$ \\
\hline Coagulation of milk & $-\left(37^{\circ} \mathrm{C}\right)$ \\
\hline Cellulolytic activity & - \\
\hline \multicolumn{2}{|c|}{$\begin{array}{l}\text { * }+ \text {, Active; }- \text {, not active. } \\
\text { Melanin formation is active in tryptone - yeast } \\
\text { medium, but not active in tyrosine agar, pep- } \\
\text { tone - yeast extract-iron agar and glucose - } \\
\text { peptone - gelatin (stab culture). }\end{array}$} \\
\hline
\end{tabular}

Table 3. Utilization of carbon sources by strain AM-6424.

\begin{tabular}{lc}
\hline \multicolumn{1}{c}{ Carbon source } & Utilization* \\
\hline D-Glucose & + \\
D-Fructose & + \\
L-Rhamnose & - \\
L-Arabinose & + \\
$i$-Inositol & + \\
Raffinose & \pm \\
D-Xylose & + \\
Sucrose & - \\
D-Mannitol & + \\
Melibiose & + \\
Cellulose & - \\
\hline$*$ +, Utilized;, \pm weakly utilized; - , not utilized.
\end{tabular}

Spira type. The spores are cylindrical. The spore surface is smooth with some winkled forms. Sclerotic granules, sporangia and flagellated spores were not observed.

Chemotaxonomy

The chemical analyses of sugars in whole cells and diaminopimelic acid $\left(\mathrm{A}_{2} \mathrm{pm}\right)$ in cell wall were carried out by the methods of LeCHeVAlier and LeCheVAlier. ${ }^{1)}$ Strain AM-6424 showed presence of LL- $\mathrm{A}_{2} \mathrm{pm}$ in the cell wall and no characteristic sugar pattern.

Cultural and Physiological Characteristics

The International Streptomyces Project (ISP) media recommended by SHIRLING and GotTLIEB ${ }^{2)}$ and those recommended by WAKSMAN ${ }^{3)}$ were used. Cultures were observed after incubation at $27^{\circ} \mathrm{C}$ for two weeks. Color names and hue numbers indicated in Table 1 are those of Color Harmony Manual (4th edition) published by Container Corporation of America. The utilization of carbon sources was tested by growth on Pridham and GotTLIEB's medium containing $1 \%$ carbon source each. The cultural and physiological characteristics, and the utilization of carbon sources of strain AM-6424 are shown in Tables 1, 2 and 3, respectively.

Strain AM-6424 exhibits the following properties. Sporophore, Spira; spore, cylindrical; spore surface, smooth; color of vegetative mycelium, gold or brown; color of aerial mycelium, white or ivory; production of melanoid pigment, active; soluble pigment, yellow or gold; $\mathrm{A}_{2} \mathrm{pm}$ in cell wall, LL-type.

Based on the taxonomic properties described above, strain AM-6424 is considered to belong to the genus Streptomyces and to be a strain of the white series of the PridHAm and Tresner grouping ${ }^{4)}$. Strain AM-6424 has been deposited in Fermentation Research Institute, Agency of Industrial Science and Technology, Japan, under the name Streptomyces sp. AM-6424 and the accession No. FERM-P 6791.

\section{Production and Isolation}

The stock culture of strain AM-6424 was inoculated into $100 \mathrm{ml}$ of a seed medium consisting of $2 \%$ glucose, $0.5 \%$ meat extract, $0.5 \%$ peptone, $0.3 \%$ dried yeast, $0.5 \% \mathrm{NaCl}$ and $0.3 \% \mathrm{CaCO}_{3}$ in a $500-\mathrm{ml}$ Sakaguchi flask and incubated at $27^{\circ} \mathrm{C}$ for 48 hours. Three hundred milliliters of a thus obtained seed culture was transferred to 30 liters of a production medium in a 50-liter jar fermentor and the fermentation was carried out at $27^{\circ} \mathrm{C}$ with agitation of $250 \mathrm{rpm}$ and aeration of 10 liters/minute. The composition of the production medium was $2 \%$ starch, $0.5 \%$ glycerol, $0.25 \%$ soybean meal, $0.5 \% \mathrm{NH}_{4} \mathrm{Cl}, 0.1 \%$ 
$\mathrm{K}_{2} \mathrm{HPO}_{4}$ and $0.15 \% \mathrm{Ca}_{3}\left(\mathrm{PO}_{4}\right)_{2}$ (presterile $\mathrm{pH} 6.8$ ). The antibiotic production started at $15 \sim 20$ hours after inoculation then gradually increased and reached a maximum $(2 \mu \mathrm{g} / \mathrm{ml})$ at 39 hours.

A 42-hour culture (30 liters) was clarified with a Sharples centrifuge to obtain about 28 liters of a supernatant fluid. The fluid was adjusted to $\mathrm{pH} 7.2$ with $2 \mathrm{~N} \mathrm{NaOH}$ and treated with $500 \mathrm{ml}$ of Amberlite IRC-50 $\left(\mathrm{Na}^{+}\right)$in a batchwise operation. The antibiotic in the effluent was adsorbed on an activated carbon column $(20 \times 9 \mathrm{~cm})$, and eluted with $40 \%$ acetone. The active fractions were combined, concentrated in vacuo to a small volume and lyophilized to obtain $41.6 \mathrm{~g}$ of crude powder. The powder was chromatographed on an Avicel column $(45 \times 6.5 \mathrm{~cm})$, eluting with a mixed solvent of methanol and water (6:1). The active fractions were combined, concentrated in vacuo to $100 \mathrm{ml}$ and lyophilized to give $820 \mathrm{mg}$ of yellowish brown powder. The powder was dissolved in $1 \mathrm{ml}$ of water and applied on a Sephadex LH-20 column $(90 \times 3 \mathrm{~cm})$ previously equilibrated with water. The antibiotic was eluted with water. The active fractions were combined, concentrated in vacuo to $10 \mathrm{ml}$ and lyophilized to give a pale yellow powder $(40 \mathrm{mg})$. The antibiotic was then purified by preparative thin-layer chromatography (TLC) on Avicel developing with 1-butanol - acetic acid - water (3:1:1). The active zone was cut out from TLC and eluted with water. The eluate was concentrated in vacuo to $1 \mathrm{ml}$ and lyophilized to give a pale yellow powder $(16.6 \mathrm{mg})$. The powder was dissolved in $0.5 \mathrm{ml}$ of water and chromatographed on Sephadex LH-20 column eluting with water. The active fraction were combined, concentrated in vacuo to $1 \mathrm{ml}$ and lyophilized to yield $5.5 \mathrm{mg}$ of pure karabemycin as a white powder.

The antibiotic activity was assayed by paper disc method against Bacillus subtilis PCI 219 on synthetic agar plates. The antibiotic was also detected by Avicel TLC: Solvent, 1-propanol - pyridine -

Table 4. Physicochemical properties of karabemycin.

\begin{tabular}{|c|c|}
\hline Appearance & White powder, weakly basic \\
\hline Melting point & $280 \sim 282^{\circ} \mathrm{C}$ (dec.) \\
\hline Optical rotation & {$[\alpha]_{\mathrm{D}}^{20}-40.3^{\circ}\left(c 0.55, \mathrm{H}_{2} \mathrm{O}\right)$} \\
\hline \multicolumn{2}{|l|}{ Elemental analysis $(\%)$} \\
\hline \multicolumn{2}{|c|}{ Calcd. for $\mathrm{C}_{15} \mathrm{H}_{24} \mathrm{~N}_{4} \mathrm{O}_{6} \cdot 2 \mathrm{H}_{2} \mathrm{O}$} \\
\hline Found & C $46.51, \mathrm{H} 6$ \\
\hline Molecular formula & $\mathrm{C}_{15} \mathrm{H}_{24} \mathrm{~N}_{4} \mathrm{O}_{6}$ \\
\hline Mass FD-MS: $m / z$ & $357\left[(\mathrm{M}+\mathrm{H})^{+}\right]$ \\
\hline $\begin{array}{ll}\text { Color reaction } & (+) \\
& (-)\end{array}$ & $\begin{array}{l}\text { Ninhydrin, RYDON-SMITH } \\
\text { p-Anisidine, DRAGENDORFF }\end{array}$ \\
\hline $\mathrm{UV}\left(\mathrm{H}_{2} \mathrm{O}\right)$ & End absorption \\
\hline $\mathrm{IR}, \nu_{\max }^{\mathrm{KBr}} \mathrm{cm}^{-1}$ & $\begin{array}{l}3250,2950,1740,1640,1580, \\
1380\end{array}$ \\
\hline$p K a$ & 9.2 \\
\hline \multirow[t]{2}{*}{ Solubility } & $\mathrm{H}_{2} \mathrm{O}$, DMSO \\
\hline & $\begin{array}{l}\text { Chloroform, ethyl acetate, } \\
\text { benzene, } n \text {-hexane }\end{array}$ \\
\hline Rf values (Avicel TLC) & $\begin{array}{l}\text { 1- } \mathrm{PrOH} \text { - pyridine - } \mathrm{AcOH} \text { - } \\
\mathrm{H}_{2} \mathrm{O}(15: 10: 3: 6), \mathrm{Rf} 0.47 \\
1-\mathrm{BuOH}-\mathrm{AcOH}-\mathrm{H}_{2} \mathrm{O} \\
(3: 1: 1), \text { Rf } 0.42\end{array}$ \\
\hline $\begin{array}{l}\text { Amino acid analysis } \\
\text { (molar ratio) }\end{array}$ & $\begin{array}{l}\text { Valine (1.0), alanine (1.0), } \\
\text { unknown (1.0) }\end{array}$ \\
\hline
\end{tabular}
acetic acid - water (15: $10: 3: 6)$; detection, ninhydrin; Rf value, 0.47 .

\section{Physicochemical Properties}

Table 4 shows the physicochemical properties of karabemycin. The molecular formula of karabemycin was proposed to be $\mathrm{C}_{15} \mathrm{H}_{24} \mathrm{~N}_{4} \mathrm{O}_{8}$ (MW 356) from the elemental analysis, FD-mass, and, ${ }^{1} \mathrm{H}$ and ${ }^{13} \mathrm{CNMR}$. The formula $\mathrm{C}_{15} \mathrm{H}_{24} \mathrm{~N}_{4} \mathrm{O}_{6}$ is supported by the FD-mass analysis of DNPkarabemycin: $\mathrm{M}^{+} m / z 523$ and $(\mathrm{M}+\mathrm{Na})^{+} m / z$ 546. In the IR spectrum of karabemycin (Fig. 1), the presence of amide bonds was observed at $1640 \mathrm{~cm}^{-1}$ and $1580 \mathrm{~cm}^{-1}$. The acid hydrolysate $\left(6 \mathrm{~N} \mathrm{HCl}, 110^{\circ} \mathrm{C}, 12\right.$ hours) gave one molar each of valine, alanine and an unknown amino acid. Figs. 2 and 3 show the ${ }^{1} \mathrm{H}$ and ${ }^{13} \mathrm{C}$ NMR spectra of karabemycin, respectively. The four carbon signals of amide carbonyl and ester carbon groups at 178.3, 174.5, 171.5 and $169.6 \mathrm{ppm}$ were observed (Fig. 3). From the analyses mentioned above, karabemycin is considered to be a tripeptide antibiotic. 
VOL. XXXVI NO. 9

Fig. 1. IR spectrum of karabemycin $(\mathrm{KBr})$.

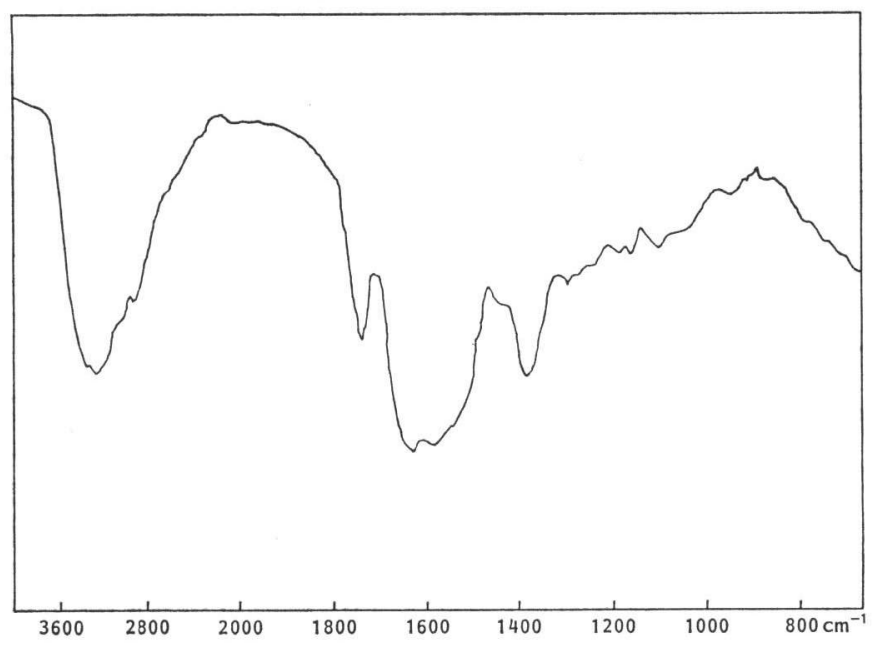

Fig. 2. ${ }^{1} \mathrm{H}$ NMR spectrum $\left(400 \mathrm{MHz}, \mathrm{D}_{2} \mathrm{O}\right)$ of karabemycin.

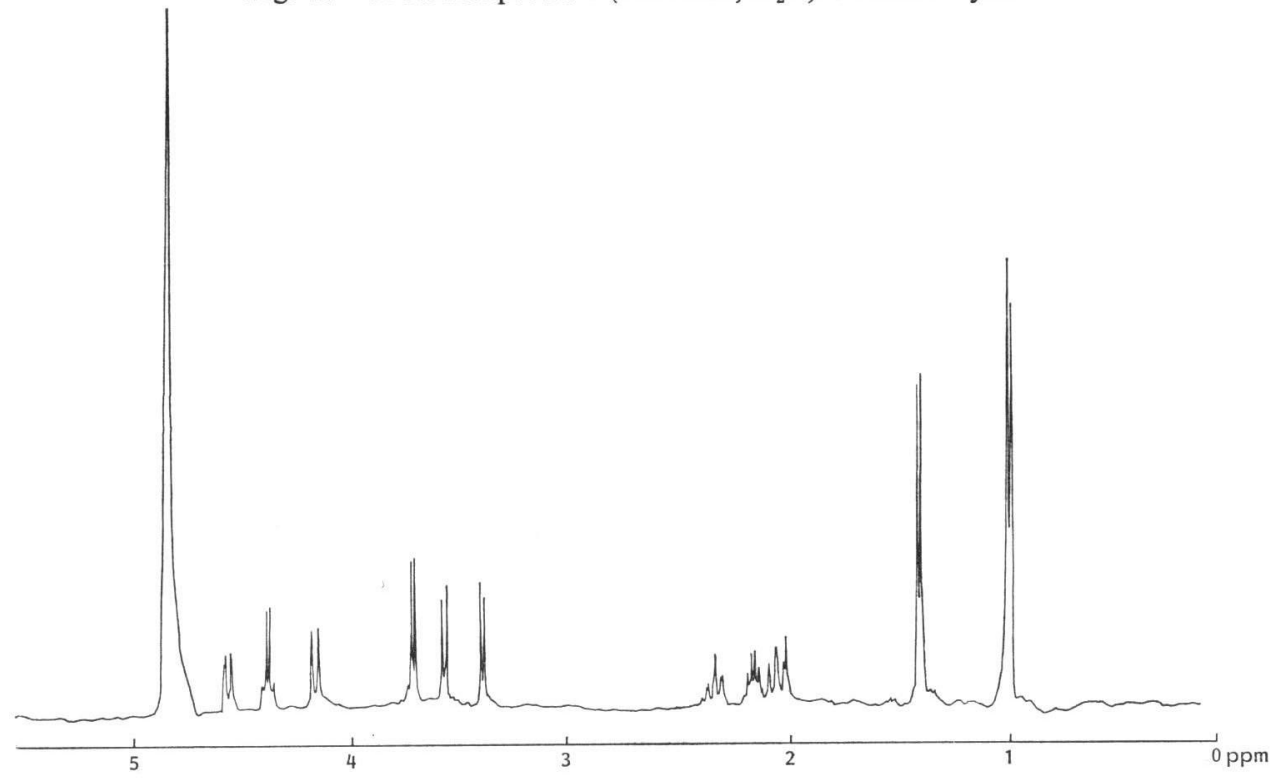

Fig. 3. ${ }^{13} \mathrm{C}$ NMR spectrum $\left(25 \mathrm{MHz}, \mathrm{D}_{2} \mathrm{O}\right)$ of karabemycin.

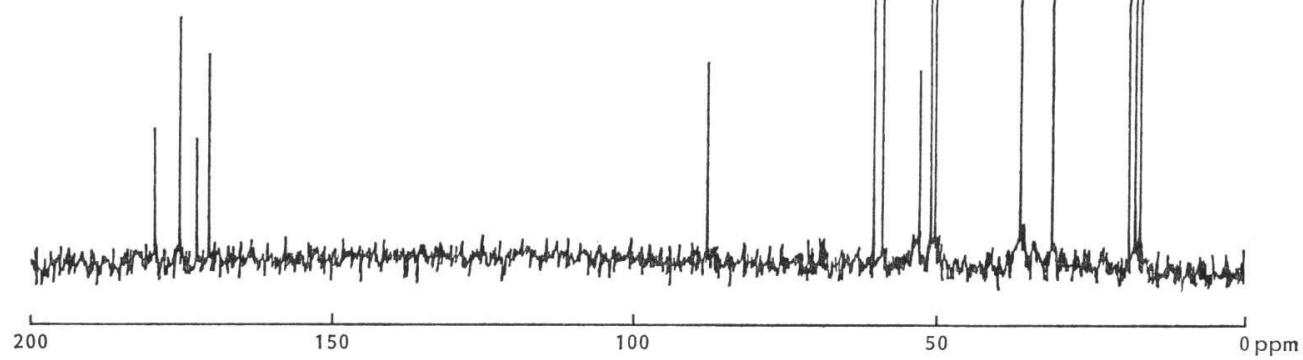


Table 5. Antimicrobial spectrum of karabemycin by paper disc method.*

\begin{tabular}{lcc}
\hline \multicolumn{1}{c}{ Test organism } & Medium** & $\begin{array}{c}\text { Inhibition } \\
\text { zone } \\
\text { (mm) }\end{array}$ \\
\hline Bacillus subtilis PCI 219 & 1 & - \\
Staphylococcus aureus & 2 & 40.2 \\
$\quad$ IFO 12732 & 1 & - \\
Escherichia coli IFO 12734 & 1 & - \\
& 2 & 35.4 \\
Pseudomonas aeruginosa & 1 & 15.0 \\
IFO 12689 & 2 & 45.2 \\
P. lachrymans & 1 & 18.8 \\
Erwinia carotovora & 1 & - \\
Klebsiella pneumoniae & 2 & 62.4 \\
$\quad$ IFO 3512 & 1 & - \\
Alkaligenes faecalis & 1 & - \\
Candida albicans IFO 1060 & 3 & - \\
Aspergillus niger ATCC 6275 & 3 & - \\
& 5 & - \\
\hline
\end{tabular}

* Paper disc, $8 \mathrm{~mm}$ in diameter; karabemycin, $1,000 \mu \mathrm{g} / \mathrm{ml}$.

** 1: Nutrient agar.

2: $4 \mathrm{~g}$ glucose, $1 \mathrm{~g} \mathrm{NH}$ Cl, $5.8 \mathrm{~g} \mathrm{Na}_{2} \mathrm{HPO}_{4}, 3 \mathrm{~g}$ $\mathrm{KH}_{2} \mathrm{PO}_{4}, 0.5 \mathrm{~g} \mathrm{NaCl}, 0.011 \mathrm{~g} \mathrm{CaCl}_{2} \cdot 2 \mathrm{H}_{2} \mathrm{O}$, $0.246 \mathrm{~g} \mathrm{MgSO}_{4} \cdot 7 \mathrm{H}_{2} \mathrm{O}, 15 \mathrm{~g}$ agar, water $1,000 \mathrm{ml}$.

3: Potato - sucrose agar.

4: $20 \mathrm{~g}$ glucose, $2.0 \mathrm{~g}$ asparagine, $2.0 \mathrm{~g}\left(\mathrm{NH}_{4}\right)_{2}$ $\mathrm{SO}_{4}, 1.5 \mathrm{~g} \mathrm{KH}_{2} \mathrm{PO}_{4}, 0.33 \mathrm{~g} \mathrm{CaCl} \cdot 2 \mathrm{H}_{2} \mathrm{O}$, $0.5 \mathrm{~g} \mathrm{MgSO}_{4} \cdot 7 \mathrm{H}_{2} \mathrm{O}, 0.1 \mathrm{mg} \mathrm{KI}, 5 \mathrm{mg}$ yeast extract, $15 \mathrm{~g}$ agar.

5: Czapek agar.
Table 6. Effect of karabemycin on the growth of plant roots.

\begin{tabular}{ccc}
\hline \multirow{2}{*}{$\begin{array}{c}\text { Karabemycin } \\
(\mu \mathrm{g} / \mathrm{ml})\end{array}$} & \multicolumn{2}{c}{ Inhibition* $(\%)$} \\
\cline { 2 - 3 } & Oryza sativa & $\begin{array}{c}\text { Raphanus } \\
\text { sativus }\end{array}$ \\
\hline 500 & 72.2 & 80.0 \\
250 & 52.2 & 67.4 \\
125 & 23.4 & 61.1 \\
62.5 & 10.3 & 15.4 \\
31.3 & 2.3 & 4.3 \\
\hline
\end{tabular}

* Inhibition $(\%)=\mathrm{A}-\mathrm{B} / \mathrm{A} \times 100$

$\mathrm{A}$, root length in non-treated class

$\mathrm{B}$, root length in treated class with karabemycin

Five milliliters of karabemycin aqueous solution was added to a Petri dish $(7.5 \mathrm{~cm}$ in diameter). Five seeds of Oryzae sativa or Raphanus sativus per dish were inoculated into the Petri dish. The seeds were incubated at $25^{\circ} \mathrm{C}$ for 5 days under a fluorescent lamp.

\section{Biological Properties}

Table 5 shows the antimicrobial spectrum of karabemycin. The antibiotic was active against some bacteria on a synthetic agar medium, but was inactive or weakly active against bacteria on a complex agar medium and was inactive against fungi. The inhibitory activity of karabemycin against bacteria on a synthetic agar medium was reversed by L-glutamine and L-glutamic acid.

Karabemycin has inhibitory activity on the growth of plant roots (Table 6). Karabemycin

$(500 \mu \mathrm{g} / \mathrm{ml})$ did not show any toxic symptoms to RK-13 cells grown in tissue culture.

\section{Discussion}

Karabemycin was isolated from the culture filtrate of Streptomyces sp. AM-6424. The antibiotic was found to be an antimetabolite of glutamine (glutamic acid), and a tripeptide antibiotic consisting of alanine, valine and an unidentified amino acid. Karabemycin was compared with known antibiotics of actinomycetes origin, such as antimetabolites of glutamine (glutamic acid) and peptide antibiotics. However, because none of their physicochemical properties was identical with those of karabemycin, it is reasonable to conclude that karabemycin is new.

A paper describing structure elucidation of karabemycin is now in preparation.

\section{Acknowledgment}

The authors are grateful to Dr. M. URAмото, The Institute of Physical and Chemical Research for NMR spectrometric analyses. We wish to thank Miss S. TAGA of Kitasato University for her technical assistance. 


\section{References}

1) Lechevalier, M. P. \& H. A. Lechevalier: The chemotaxonomy of actinomycetes. Textbook of Actinomycetes Taxonomy. Workshop. Soc. Ind. Microbiol., Aug. 13, 1978, pp. 1 49, 1978

2) Shirling, E. B. \& D. Gottlieb: Methods for characterization of Streptomyces species. Int. J. Syst. Bacteriol. 16: $313 \sim 340,1966$

3) Waksman, S. A.: The actinomycetes. Vol. 2. The Williams \& Wilkins Co., Baltimore, 1961

4) Pridham, T. G. \& H. D. Tresner: Bergey's Manual of Determinative Bacteriology. 8th ed., pp. 748 829, The Williams \& Wilkins Co., Baltimore, 1974 